PROBLEMS

OF EDUCATION

IN THE $21^{\text {st }}$ CENTURY

Volume 43, 2012

\section{EVALUATION OF ATTITUDES AND INTERESTS TOWARDS ICT: ORIENTATION FOR PROBLEM EXPERIENCES}

\author{
Francisco Manuel Morales Rodríguez \\ University of Malaga, Spain \\ E-mail: framorrod@uma.es
}

\begin{abstract}
The transformation process occurring in the educational field, which has resulted from the generalized development and application of the Information and Communication Technologies (ICT), differs from preceding technological revolutions in the amazingly accelerated pace it sets. Reflecting upon the implications of the generalized and increasing adoption of ICT is undeniably important for the present and future of social sciences and, particularly, for the areas of pedagogy and didactics. The new model of Higher Education involves new methods, demands and challenges, where the use of ICT represents one of the basic competences. The present study aims to provide an evaluation of interests and attitudes towards Information and Communication Technologies (ICT) in a sample of 224 post-graduate students of the Master's Degree in Teacher Training: Secondary and Upper Secondary Education, Vocational Training and Language Teaching, aged from 22 to 49 years old. The questionnaire includes questions aimed to evaluate different aspects, which facilitate interactive learning: computer knowledge; knowing the value of the Internet; place and frequency of online access; and usefulness of certain tools such as videofilm, power point, Moodle, forums, wikis, chats, video-forums and blogs. Additionally, the questionnaire includes a number of questions about the potential applications of the Internet in an educational context. Results showed that all students are familiar with the Internet and that they first got to know it from friends. More important is the fact that most of them consider the Internet as a potential educational resource and not only as a support or reinforcement tool that complements the textbook and they like to use ICT and think of them as useful tools in their learning/teaching process. There are differences based on gender and specialization in the perception of the role that ICT is to play in the university context. In particular, men from the specialization Foreign Language consider that weblogs do facilitate peer-topeer and student-teacher communication and give less importance than women to the item stating that the families' socioeconomic level has an influence on our knowledge of the Internet. To conclude, the information obtained from the present study is of interest both for training teachers and for integrating ICT in the academic curricula.
\end{abstract}

Key words: attitudes, ICT, learning, university students.

\title{
Introduction
}

Since the beginning of the $21^{\text {st }}$ Century, a series of technological, cultural, demographic, political and economic factors have changed the game rules in institutions and organisations. One of the most significant changes is how the massive access to Information and Communication Technologies (ICT) is changing our conception of time and technology itself.

The current technological development of our societies, together with a new political boost to promote technologies, plays a crucial role in globalisation (and in its costs and benefits). Technological progress has led to a smaller world and a cheaper exchange of goods. European culture has attempted to maintain both competitiveness and social cohesion without neglecting 
the Welfare State, in an ongoing search to maintain the necessary balance between solidarity and efficiency. Innovation has become a real need, and the human factor that is present in the different organisations has become a guarantee of survival, development, social progress and growth.

The New Model of Higher Education involves new methods, demands and challenges, where the use of ICT (especially the Internet) as educational tools plays a crucial role in the teaching/learning process. Digital technologies can have many advantages and can greatly contribute to the educational field nowadays. Yet in some work areas the use of ICT seems to be generating controversy and can be looked on with distrust. It is evident that the use of these technologies has both advantages and disadvantages (Cabero and Gisbert, 2005; García-Valcárcel, 2007; Sangrá and González, 2004); hence the need to identify which of these technologies can be used with an educational purpose, in view of the competences students must develop according to the European Higher Education Area. Among the disadvantages, Carr (2011) stresses their potential detrimental effects on cognition, diminishing the capacity for concentration and contemplation. In other words, students can quickly search and share information, but they may also find that their capacity for reading and for holding a line of thought on any topic for a certain amount of time is diminished. Nevertheless, there are many emerging studies (Barroso and Cabero, 2010; Cebrián and Gallego, 2011; and De Pablos, Area, Valverde and Correa, 2010) on the educational process involving ICT in the knowledge society, and their application in the university context. Among such studies, it is worth highlighting the following advantages: the possibility of implementing different teaching/learning models, which are innovative, interactive and adapted to different types of students; the emergence of webpages for university subjects; the spread of information to countless people and institutions worldwide; the possibility of interaction between educational agents, namely teachers and students; the more active role of students; the optimization of meaningful learning; the emergence of new communication channels, hence favouring the emergence of distribution lists; work groups and discussion forums; cooperation in the development of teaching materials, etc.

The Bologna Declaration marks the beginning of the construction process of this space, aimed at responding to the European Union's initiative to create a homogeneous system of higher education. The purpose is to promote the development of all members and citizens' mobility, employability and capacity of innovation (Rubio and Álvarez, 2010). In this line, Royal Decree 55/2005 officially regulates university postgraduate studies, providing the gateway to degree courses. Bachelor degree courses are expected to respond to teaching needs in the future, by incorporating ICT into the learning process through innovative educational methods. The university curricula must analyse and assess students', teachers' and institutions' attitudes toward such methods in more detail, in such a way that they contribute to facilitate online lifelong learning processes and shape an ongoing innovation process, which is able to incorporate the best international educational practices and the most advanced technological applications.

In this context of the European convergence process, young students must be trained in different competences, that will enable them to successfully cope in the professional field. They must be highly qualified in order to keep up with the economic, intellectual and cultural progress demanded by our societies. The cooperative and participative methodologies offered by Web 2.0 are required to promote the acquisition of such competences. In this line, Fernández and Mena (2010) state that the teachers' role and conception of teaching have also changed. Teachers must now develop new competences, both personally and professionally, involving the use of ICT tools, initiative, creativity, group work, problem-solving strategies, etc. to create the knowledge that will allow them to successfully face the new challenges ahead. Mediators must adopt a new role to promote the ability to co-operate as well as critical thinking.

Other experts (Ríos and Ruiz, 2011) also consider ICT essential to face many of the 
PROBLEMS

OF EDUCATION

IN THE $21^{\text {st }}$ CENTURY

Volume 43, 2012

46

difficulties and problems in society, and suggest that competences such as attitudes, skills, knowledge or values must be under constant evaluation. Students, teachers and university authorities are expected to be involved in the development of an educational model based on competences. In this model, it is essential for students, who are part of higher education institutions and are the real actors in the teaching/learning process, to feel supported in order to guarantee their success and professional satisfaction in the university and productive spheres. To such end, students' assessment needs to be more accurate (such as the one put forward in the present study) to be able to reflect their interests and attitudes regarding ICTs as learning and communication tools.

In the university context, there is some research (De Pablos, 2009; Trujillo, 2005) on the need to limit the indiscriminate use of ICT, to reflect on what the changes associated to them might bring, and considering aspects such as their degree of utility and adaptability. In this sense, one of the most important elements in the process of integrating ICTs in universities is to know students' opinions and attitudes towards the use of these technologies in their learning process (Martínez and Aguaded, 2004). For all the reasons mentioned above, the aim of the present study is to provide an evaluation of interests and attitudes towards ICTs in a sample of 224 postgraduate students of the Master's Degree in Teacher Training: Secondary and Upper Secondary Education, Vocational Training and Language Teaching, in the specialities of Foreign Language (English and French); Literature, Latin and Greek; and Technology, Computer Science and Industry. Differences will be analysed according to gender and specialization.

The above information draws conclusions about the importance of using ICT in the teaching/learning process, as well as the potential advantages and disadvantages of their use by teachers and post-graduate students of the Master's Degree in Teacher Training.

\section{Research Design}

Over the last few years, there has been a deep change in the way of teaching and learning. The focus is now on cooperative learning and cooperative groups, using online tools. This is a socio-constructive approach that favours education, based on cooperative work represented by learning communities where all members learn "from and with" one another, under the principles of diversity, tolerance, negotiation, dialogue, cooperation, empathy and consensus decision-making that will provide multiple answers to the same situation in different contexts. In particular, the massive access to ICT is changing our conception of time and transforming our institutions and organisations. The new model of Higher Education involves new methods, demands and challenges, where the use of ICT represents one of the basic competences. The development of the digital competence and treatment of information can have many advantages and can greatly contribute to the educational field nowadays. Yet in some work areas, the use of ICT seems to be generating controversy can be looked upon with distrust. The use of these technologies can have both advantages and disadvantages (García-Valcárcel, 2007; Sangrá and González, 2004); hence the need to identify which can be used with an educational purpose, in view of the competences students must learn according to the European Higher Education Area. In the university context, there is some research (De Pablos, 2009; Trujillo, 2005) on the need to limit the indiscriminate use of ICT, to reflect on what the changes associated to them might bring, considering aspects such as their degree of utility and adaptability. In this sense, one of the most important elements in the process of integrating ICT in university is to know students' opinions and attitudes towards the use of ICT in their learning process (Martínez and Aguaded, 2004), as gathered in the present study. 


\section{Research Methodology}

\section{General Background of Research}

In the middle of the European convergence process, young students must be prepared in competences that will enable them to successfully cope in the professional field. They must be highly qualified in order to keep up with the economic, intellectual and cultural progress demanded by our societies. The cooperative and participative methodologies offered by Web 2.0 are required so as to promote the acquisition of such competences. In this line, Fernández and Mena (2010) state that teachers' roles and conceptions of teaching have also changed. Teachers must now develop new competences, both personally and professionally, involving the use of ICT tools. In order to create the knowledge that will enable students to successfully face the new challenges in the university context, a more accurate evaluation of interests and attitudes towards ICT is required, such as the one gathered in the present study. Descriptive analyses are presented here, including percentages, means and standard deviations. Additionally, the Student T-test was conducted in independent samples to check if there were statistically significant differences according to gender and specialization, in the Master's Degree in Teacher Training: Secondary and Upper Secondary Education, Vocational Training and Language Teaching.

\section{Research Sample}

The group of participants was made up of 224 students, aged between 22 and 49 years old, studying the Master's Degree in Teacher Training: Secondary and Upper Secondary Education, Vocational Training and Language Teaching. 64 were studying the specialization of Foreign Language (English and French); 58 Literature, Latin and Greek; and 102 were divided into two shifts (morning and afternoon) for the specialization of Technology, Computer Science and Industry. The class group completed the questionnaire in a collective application.

\section{Instrument and Procedure}

Interests and Attitudes Towards ICT Questionnaire (Morales, 2009). Instructions to complete the questionnaire were also provided. As mentioned earlier, the questions gathered in the questionnaire refer to students' computer knowledge, frequency and place of online access, and questions about students' opinion of the usefulness of watching videos, power point presentations, Moodle platforms, forums, wikis, chats, video forums and blogs throughout their learning process; as well as their opinion on the potential applications of the Internet in the university context. The questionnaire is presented in a series of multiple-choice questions, where participants must circle the option that best corresponds with their answer. In order to assess the potential applications of the Internet in the educational context, a Likert scale was used to measure to what degree students agree with a number of statements, ranging from $0=$ not at all; $1=\mathrm{a}$ little, $2=$ quite, $3=\mathrm{a}$ lot. The questionnaire presents adequate psychometric properties.

Participants completed the questionnaire on a voluntary basis, and data was introduced in the SPSS for its subsequent analysis. The evaluation instrument was collectively administered to students during class hours, following the dates and timetable of the university academic calendar. The questionnaire was conducted by expert psychologists in the field. 
PROBLEMS

OF EDUCATION

IN THE $21^{\text {st }}$ CENTURY

Volume 43,2012

48

\section{Data Analysis}

The data coding and analysis was carried out by means of the Statistical Package for the Social Sciences SPSS 15.0. In addition to conducting descriptive analyses reflecting percentages, means and standard deviations, a Student T-test was conducted in independent samples to check if there were statistically significant differences according to gender and specialization in the Master's Degree in Teacher Training: Secondary and Upper Secondary Education, Vocational Training and Language Teaching. More specifically, the present study compares results derived from interests and attitudes towards ICT of students of the specializations of Foreign Language (English and French); Literature, Latin and Greek; and Technology, Computer Science and Industry. It is worth mentioning that the study only presents the tables with the comparative analyses of the results were statistically significant differences have been found.

\section{Research Results}

The first section of the study shows the results of the post-graduate student sample with regards to their interests and attitudes towards the Internet (Table 1), as well as their general computer knowledge (Table 2). Likewise, this section also shows the students' degree of agreement with ICT applications in the university context (Table 3). In this line, an accurate evaluation of students' attitudes becomes necessary, as contemplated in the organisation of the Master's Degree, and as set forth in the present study.

The second section of the study only shows the statistically significant analyses of mean differences according to gender and specialization with regards to ICT applications in the university context, after conducting a Student T-test in independent samples (Tables 4 and 5).

In Table 1 we observe that all students $(100 \%)$ are familiar with the Internet. When asked how they first came to know of the Internet, $39.02 \%$ of students state to have got to know it through friends, $21.95 \%$ from school and the rest from family, TV or other media. Likewise, all participants have a PC. Most of them usually access it from their home (48.44\%), with a frequency of one or several times a day, and do not have a webpage. The most commonly used online services are as follows (by order of use): email (26.89\%); web search engines $(26.89 \%)$; forums $(21.85 \%)$; chats $(12.60 \%)$ and further services such as social networks $(11.76 \%) .100 \%$ of students think that the Internet can become an addiction. $100 \%$ of students think that the Internet can be used as a teaching tool. With regards to the extent to which they like the Internet, students reached a mean score of 9.21 in a $0-10$ scale. 
Francisco Manuel MORALES RODRÍGUEZ. Evaluation of Attitudes and Interests towards ICT: Orientation for Problem Experiences

Table 1. Interests and Attitudes Towards the Internet in Postgraduate Students of the Master's Degree in Teacher Training (\%).

\begin{tabular}{|l|c|c|}
\hline Do you know what the Internet is? & No & 0 \\
\hline & Yes & 100 \\
\hline You first got to know it from: & Friends & 39.02 \\
\hline & School & 21.95 \\
\hline & Family & 24 \\
\hline & TV & 2 \\
\hline Do you have a PC? & Other media & 12 \\
\hline & Yes & 100 \\
\hline You access your PC from: & No & 0 \\
\hline & High School & 3.12 \\
\hline & College & 32.81 \\
\hline & Internet café & 3.12 \\
\hline & Home & 48.44 \\
\hline Frequency of use: & Work or other places & 12.50 \\
\hline & 1 or several times/day & 97 \\
\hline Services: & 1 or several times/week & 3 \\
\hline & Email & 26.89 \\
\hline & Chat & 12.60 \\
\hline & Forums & 21.85 \\
\hline & Web search engines & 26.89 \\
\hline Do you have a webpage? & Others (social networks, etc.) & 11.76 \\
\hline & Yes & 21.87 \\
\hline Can the Internet become an addiction? & No & 78.12 \\
\hline & Yes & 100 \\
\hline Can the Internet be used as a teaching & No & 0 \\
\hline tool? & Yes & 100 \\
\hline & No & 0 \\
\hline
\end{tabular}

As stated by participants, in general terms, their computer knowledge is user level knowledge, i.e. they are familiar with databases and spreadsheets, but they have less knowledge about programming. The summarised data with the corresponding percentages are shown in Table 2.

Table 2. General Computer Knowledge (\%).

\begin{tabular}{|c|c|c|c|}
\hline \multicolumn{4}{|c|}{ Level of Students' General Computer Knowledge } \\
\hline & Low & User Level & High \\
\hline Text Processors & 0 & 36.67 & 63.33 \\
\hline Databases & 25.8 & 51.61 & 22.58 \\
\hline Spreadsheets & 19.35 & 64.52 & 16.13 \\
\hline The Internet & 0 & 27.59 & 72.41 \\
\hline Graphic Design & 47.05 & 44.12 & 8.82 \\
\hline Animation & 55.55 & 27.77 & 16.67 \\
\hline Programming & 74.19 & 12.9 & 12.9 \\
\hline
\end{tabular}


PROBLEMS

OF EDUCATION

IN THE $21^{\text {st }}$ CENTURY

Volume 43,2012 educational context. The results were obtained from a sample of students of the Master's Degree in Teacher Training using a Likert scale and were based on the degree of agreement with certain statements (see Table 3).

Table 3. ICT Applications in the University Context (\%).

\begin{tabular}{|c|c|c|c|c|}
\hline & Not at all & A little & Quite & A lot \\
\hline 1. The Internet can be used for teaching & 0 & 0 & 32.5 & 67.5 \\
\hline 2. The Internet can replace the teacher's function & 44.74 & 44.74 & 10.53 & 0 \\
\hline $\begin{array}{l}\text { 3. The Internet can only be used by students with a high intellectual } \\
\text { level }\end{array}$ & 65.90 & 34.09 & 0 & 0 \\
\hline 4. The Internet can replace the function of books and whiteboards & 10 & 30 & 47.5 & 12.5 \\
\hline $\begin{array}{l}\text { 5. The Internet can be combined with teacher's explanations on the } \\
\text { whiteboard }\end{array}$ & 3.12 & 3.12 & 25 & 68.75 \\
\hline 6. Learning through the Internet is more useful, fun and beneficial & 0 & 29.73 & 43.24 & 27.02 \\
\hline 7. The Internet conveys positive values & 0 & 35.13 & 54.05 & 10.81 \\
\hline $\begin{array}{l}\text { 8. The Internet can currently only be used in favourable socio-economic } \\
\text { areas }\end{array}$ & 26.47 & 47.06 & 23.53 & 2.94 \\
\hline $\begin{array}{l}\text { 9. One's familys' socio-economic level has an influence on one's knowl- } \\
\text { edge of the Internet }\end{array}$ & 8.82 & 50 & 32.35 & 8.82 \\
\hline 10. The Internet favours the ability to relate to others & 5.40 & 37.84 & 37.84 & 18.92 \\
\hline 11. The Internet favours the use of other languages & 13.89 & 13.89 & 41.67 & 44.44 \\
\hline $\begin{array}{l}\text { 12. The Internet does not contribute to improving the relationship } \\
\text { between members of the Educational Community }\end{array}$ & 50 & 38.23 & 11.76 & 0 \\
\hline 13. With the Internet, there is no teacher-student relationship anymore & 43.24 & 43.24 & 13.51 & 0 \\
\hline 14. With the Internet, there is no classmate relationship anymore & 43.24 & 40.59 & 16.22 & 0 \\
\hline 15. The Internet helps you make new friends & 2.94 & 17.65 & 52.94 & 26.47 \\
\hline 16. The Internet isolates people from their environment & 11.11 & 44.44 & 38.89 & 5.55 \\
\hline 17. ICTs favour the educational process & 2.78 & 5.55 & 30.55 & 61.11 \\
\hline $\begin{array}{l}\text { 18. Video-watching on the Internet is very useful for acquiring new } \\
\text { knowledge, procedures and attitudes }\end{array}$ & 0 & 8.11 & 35.13 & 56.76 \\
\hline $\begin{array}{l}\text { 19. Cineforum is an interesting educational resource, both motivating } \\
\text { and facilitating more active learning }\end{array}$ & 0 & 8.82 & 47.05 & 44.12 \\
\hline $\begin{array}{l}\text { 20. Audio-visual media such as the cinema allow for values education, } \\
\text { including solidarity }\end{array}$ & 0 & 11.11 & 52.78 & 36.11 \\
\hline $\begin{array}{l}\text { 21. ICTs can be used to educate in diversity and to support socio-cultur- } \\
\text { ally disadvantaged groups }\end{array}$ & 2.78 & 5.56 & 52.78 & 38.89 \\
\hline $\begin{array}{l}\text { 22. The Internet can be used as an educational tool and not only to sup- } \\
\text { port or reinforme the textbook }\end{array}$ & 2.78 & 5.56 & 47.22 & 44.44 \\
\hline 23. The use of ICTs helps developing and organising contents effectively & 2.70 & 10.81 & 62.16 & 24.32 \\
\hline $\begin{array}{l}\text { 24. The use of ICTs can generate new more active and dynamic ways of } \\
\text { participating and communicating }\end{array}$ & 0 & 12.12 & 39.39 & 48.48 \\
\hline 25. The use of the Moodle platform facilitates the educational process & 0 & 5.71 & 51.43 & 42.86 \\
\hline 26. Weblogs facilitate peer to peer and student-teacher communication & 0 & 14.28 & 45.71 & 40 \\
\hline 27. The use of wikis allows to learn and share contents & 0 & 11.43 & 25.71 & 62.86 \\
\hline 28. Weblogs facilitate social interaction and the exchange of opinions & 0 & 5.88 & 44.12 & 50 \\
\hline $\begin{array}{l}\text { 29. The use of blogs facilitates information on news, topics of interest } \\
\text { and events related to the university subject }\end{array}$ & 0 & 5.55 & 38.88 & 55.55 \\
\hline 30. Forums facilitate the dynamic exchange of information & 2.94 & 5.88 & 41.18 & 50 \\
\hline $\begin{array}{l}\text { 31. Online tutors allow students to solve doubts and facilitate the teach- } \\
\text { ing/learning process }\end{array}$ & 0 & 17.64 & 52.94 & 29.41 \\
\hline 32. Online questionnaires help clarifying and assimilating contents & 0 & 26.47 & 47.06 & 26.47 \\
\hline 33. Power point presentations facilitate the learning process & 0 & 17.14 & 45.71 & 37.14 \\
\hline
\end{tabular}


With regards to statistically significant gender-based differences in the variable "perception of ICT applications in the university context within the specialization Foreign Language of the Master's Degree in Teacher Training" (Table 4); it can be observed that women score higher on the statement "families" socio-economic level has an influence on our knowledge of the Internet"; whereas men do so on the item stating that "weblogs facilitate peerto-peer and student-teacher communication."

Lastly, Table 5 shows the most significant results regarding students' perception and predisposition towards ICT according to each specialization. Results show that there are no statistically significant differences in relation to predisposition towards ICT between students from the specialization Foreign Language and students from Technology, Computer Science and Industry. However, there are significant differences in relation to both perception and predisposition towards ICT between students from the specialization Foreign Language and students from Literature, Latin and Greek, as shown in Table 5.

In general terms, students from the specialization Foreign Language show a higher predisposition and more positive attitudes towards the use of ICT in the teaching/learning process. These students score higher on the statements 4, 6, 7, 18, 24 and 27, namely: "the Internet can replace the function of books and whiteboards"; "learning through the Internet is more useful, fun and beneficial"; "the Internet conveys positive values"; "video-watching on the Internet is very useful to acquire new knowledge, procedures and attitudes"; "the use of ICT can generate new more active and dynamic ways of participating and communicating"; and "the use of wikis allows students to learn and share contents." However, they obtain statistically significant lower scores as compared to students from the specialization Literature, Latin and Greek in relation to the statements 12, 13 and 14, namely: "the Internet does not contribute to improving the relationship between members of the Educational Community"; "with the Internet, there is no teacher-student relationship anymore"; and "with the Internet, there is no classmate relationship anymore." 
PROBLEMS

OF EDUCATION

IN THE $21^{\text {st }}$ CENTURY

Volume 43, 2012

Table 4. Gender-based differences in the perception of ICT applications within the specialization Foreign Language.

\begin{tabular}{|c|c|c|c|}
\hline & Men & Women & $d f=65$ \\
\hline Item & Mean (SD) & $\operatorname{Mean}(S D)$ & $t$ \\
\hline 1. The Internet can be used for teaching & $3.00(1)$ & $3.26(0.88)$ & -0.56 \\
\hline 2. The Internet can replace the teacher's function & $2.00(0.70)$ & $1.53(0.74)$ & 1.38 \\
\hline $\begin{array}{l}\text { 3. The Internet can only be used by students with a high intel- } \\
\text { lectual level }\end{array}$ & $1.20(0.45)$ & $1.60(0.91)$ & -0.93 \\
\hline $\begin{array}{l}\text { 4. The Internet can replace the function of books and white- } \\
\text { boards }\end{array}$ & $2.60(0.55)$ & $2.80(0.77)$ & -0.53 \\
\hline $\begin{array}{l}\text { 5. The Internet can be combined with teacher's explanations on } \\
\text { the whiteboard }\end{array}$ & $3.40(0.55)$ & $3.47(0.64)$ & -0.21 \\
\hline $\begin{array}{l}\text { 6. Learning through the Internet is more useful, fun and benefi- } \\
\text { cial }\end{array}$ & $3.20(0.84)$ & $2.60(0.63)$ & 1.70 \\
\hline 7. The Internet conveys positive values & $3.00(0.70)$ & $2.73(0.80)$ & 0.66 \\
\hline $\begin{array}{l}\text { 8. The Internet can currently only be used in favourable socio- } \\
\text { economic areas }\end{array}$ & $1.80(0.84)$ & $2.53(0.83)$ & -1.70 \\
\hline $\begin{array}{l}\text { 9. One's familys' socio-economic level has an influence on one's } \\
\text { knowledge of the Internet }\end{array}$ & $1.60(0.55)$ & $2.60(0.74)$ & $-2.77^{* *}$ \\
\hline 10. The Internet favours the ability to relate to others & $2.00(0.70)$ & $2.60(0.99)$ & -1.25 \\
\hline 11. The Internet favours the use of other languages & $2.80(0.84)$ & $3.00(.84)$ & -0.46 \\
\hline $\begin{array}{l}\text { 12. The Internet does not contribute to improving the relation- } \\
\text { ship between members of the Educational Community }\end{array}$ & $2.40(1.34)$ & $1.73(.70)$ & 1.46 \\
\hline $\begin{array}{l}\text { 13. With the Internet, there is no teacher-student relationship } \\
\text { anymore }\end{array}$ & $1.60(.55)$ & $1.93(0.96)$ & -0.73 \\
\hline 14. With the Internet, there is no classmate relationship anymore & $2.00(1.00)$ & $1.67(0.62)$ & 0.90 \\
\hline 15. The Internet helps you make new friends & $2.20(0.84)$ & $2.93(0.96)$ & -1.52 \\
\hline 16. The Internet isolates people from their environment & $2.40(0.89)$ & $2.73(0.80)$ & -0.79 \\
\hline 17. ICTs favour the educational process & $3.20(0.84)$ & $3.40(0.74)$ & -0.51 \\
\hline $\begin{array}{l}\text { 18. Video-watching on the Internet is very useful for acquiring } \\
\text { new knowledge, procedures and attitudes }\end{array}$ & $3.40(0.55)$ & $3.26(.70)$ & 0.38 \\
\hline $\begin{array}{l}\text { 19. Cineforum is an interesting educational resource, both } \\
\text { motivating and facilitating more active learning }\end{array}$ & $3.60(0.55)$ & $3.06(0.70)$ & 1.54 \\
\hline $\begin{array}{l}\text { 20. Audio-visual media such as the cinema allow for values } \\
\text { education, including solidarity }\end{array}$ & $3.20(0.45)$ & $3.00(0.65)$ & 0.63 \\
\hline $\begin{array}{l}\text { 21. ICTs can be used to educate in diversity and to support } \\
\text { socio-culturally disadvantaged groups }\end{array}$ & $3.20(0.45)$ & $3.06(0.59)$ & 0.46 \\
\hline $\begin{array}{l}\text { 22. The Internet can be used as an educational tool and not only } \\
\text { to support or reinforce the textbook }\end{array}$ & $3.20(0.45)$ & $3.33(0.49)$ & -0.54 \\
\hline $\begin{array}{l}\text { 23. The use of ICTs helps developing and organising contents } \\
\text { effectively }\end{array}$ & $3.20(0.45)$ & $2.93(0.59)$ & 0.92 \\
\hline $\begin{array}{l}\text { 24. The use of ICTs can generate new more active and dynamic } \\
\text { ways of participating and communicating }\end{array}$ & $3.40(0.55)$ & $3.40(0.63)$ & 0.00 \\
\hline $\begin{array}{l}\text { 25. The use of the Moodle platform facilitates the educational } \\
\text { process }\end{array}$ & $3.40(0.55)$ & $3.06(0.88)$ & 0.79 \\
\hline $\begin{array}{l}\text { 26. Weblogs facilitate peer to peer and student-teacher com- } \\
\text { munication }\end{array}$ & $3.80(0.44)$ & $3.07(0.70)$ & $2.17^{*}$ \\
\hline 27. The use of wikis allows to learn and share contents & $3.60(0.55)$ & $3.53(0.64)$ & 0.21 \\
\hline $\begin{array}{l}\text { 28. Weblogs facilitate social interaction and the exchange of } \\
\text { opinions }\end{array}$ & $3.60(0.55)$ & $3.40(0.63)$ & 0.63 \\
\hline $\begin{array}{l}\text { 29. The use of blogs facilitates information on news, topics of } \\
\text { interest and events related to the university subject }\end{array}$ & $3.60(0.55)$ & $3.33(0.62)$ & 0.86 \\
\hline 30. Forums facilitate the dynamic exchange of information & $3.40(0.89)$ & $3.28(0.61)$ & 0.32 \\
\hline $\begin{array}{l}\text { 31. Online tutors allow students to solve doubts and facilitate the } \\
\text { teaching/learning process }\end{array}$ & $3.60(0.55)$ & $3.07(0.70)$ & 1.54 \\
\hline $\begin{array}{l}\text { 32. Online questionnaires help clarifying and assimilating } \\
\text { contents }\end{array}$ & $3.20(0.84)$ & $2.87(0.64)$ & 0.94 \\
\hline 33. Power point presentations facilitate the learning process & $3.20(0.45)$ & $3.13(0.74)$ & 0.19 \\
\hline
\end{tabular}

Statistical Significance. ${ }^{*} p<0.05 ;{ }^{* *} p<0.00$ 
PROBLEMS

OF EDUCATION

IN THE $21^{\text {st }}$ CENTURY

Volume 43, 2012

Table 5. Specialization-based differences in the perception of ICT applications between the specializations Foreign Language and Literature, Latin and Greek.

\begin{tabular}{|c|c|c|c|}
\hline & $\begin{array}{l}\text { Foreign } \\
\text { Language }\end{array}$ & $\begin{array}{c}\text { Literature, } \\
\text { Latin and } \\
\text { Greek }\end{array}$ & $d f=177$ \\
\hline Item & Mean (SD) & Mean (SD & $t$ \\
\hline 1. The Internet can be used for teaching & $3.42(0.81)$ & $3.34(0.54)$ & 0.46 \\
\hline 2. The Internet can replace the teacher's function & $1.64(0.68)$ & $1.37(0.49)$ & 1.90 \\
\hline $\begin{array}{l}\text { 3. The Internet can only be used by students with a high intellectual } \\
\text { level }\end{array}$ & $1.42(0.69)$ & $1.31(0.53)$ & 0.70 \\
\hline 4. The Internet can replace the function of books and whiteboards & $2.53(0.88)$ & $1.94(0.64)$ & $3.22^{* *}$ \\
\hline $\begin{array}{l}\text { 5. The Internet can be combined with teacher's explanations on the } \\
\text { whiteboard }\end{array}$ & $3.56(0.69)$ & $3.37(0.65)$ & 1.16 \\
\hline 6. Learning through the Internet is more useful, fun and beneficial & $2.92(0.69)$ & $2.40(0.77)$ & $2.98^{* *}$ \\
\hline 7. The Internet conveys positive values & $2.75(0.69)$ & $2.38(0.55)$ & $2.45^{*}$ \\
\hline $\begin{array}{l}\text { 8. The Internet can currently only be used in favourable socio-economic } \\
\text { areas }\end{array}$ & $2.03(0.88)$ & $2.29(0.98)$ & -1.16 \\
\hline $\begin{array}{l}\text { 9. One's familys' socio-economic level has an influence on one's knowl- } \\
\text { edge of the Internet }\end{array}$ & $2.39(0.84)$ & $2.60(0.95)$ & -1.00 \\
\hline 10. The Internet favours the ability to relate to others & $2.58(0.91)$ & $2.31(0.96)$ & 1.21 \\
\hline 11. The Internet favours the use of other languages & $3.11(0.82)$ & $2.97(0.74)$ & 0.75 \\
\hline $\begin{array}{l}\text { 12. The Internet does not contribute to improving the relationship } \\
\text { between members of the Educational Community }\end{array}$ & $1.74(0.83)$ & $2.26(0.74)$ & $-2.76^{* *}$ \\
\hline 13. With the Internet, there is no teacher-student relationship anymore & $1.81(0.79)$ & $2.38(0.95)$ & $-2.77^{* *}$ \\
\hline 14. With the Internet, there is no classmate relationship anymore & $1.78(0.72)$ & $2.17(0.86)$ & $-2.10^{*}$ \\
\hline 15. The Internet helps you make new friends & $2.86(0.87)$ & $2.71(0.75)$ & 0.76 \\
\hline 16. The Internet isolates people from their environment & $2.50(0.77)$ & $2.71(0.79)$ & -1.10 \\
\hline 17. ICTs favour the educational process & $3.42(0.77)$ & $3.15(0.78)$ & 1.45 \\
\hline $\begin{array}{l}\text { 18. Video-watching on the Internet is very useful for acquiring new } \\
\text { knowledge, procedures and attitudes }\end{array}$ & $3.50(0.61)$ & $3.11(0.76)$ & $2.37^{*}$ \\
\hline $\begin{array}{l}\text { 19. Cineforum is an interesting educational resource, both motivating } \\
\text { and facilitating more active learning }\end{array}$ & $3.38(0.65)$ & $3.22(0.69)$ & 0.95 \\
\hline $\begin{array}{l}\text { 20. Audio-visual media such as the cinema allow for values education, } \\
\text { including solidarity }\end{array}$ & $3.25(0.65)$ & $3.00(0.77)$ & 1.48 \\
\hline $\begin{array}{l}\text { 21. ICTs can be used to educate in diversity and to support socio-cultur- } \\
\text { ally disadvantaged groups }\end{array}$ & $3.28(0.70)$ & $3.14(0.69)$ & 0.82 \\
\hline $\begin{array}{l}\text { 22. The Internet can be used as an educational tool and not only to } \\
\text { support or reinforce the textbook }\end{array}$ & $3.30(0.71)$ & $2.97(0.86)$ & 1.79 \\
\hline $\begin{array}{l}\text { 23. The use of ICTs helps developing and organising contents ef- } \\
\text { fectively }\end{array}$ & $3.08(0.69)$ & $3.06(0.72)$ & 0.16 \\
\hline $\begin{array}{l}\text { 24. The use of ICTs can generate new more active and dynamic ways } \\
\text { of participating and communicating }\end{array}$ & $3.47(0.65)$ & $3.03(0.66)$ & $2.84^{*}$ \\
\hline 25. The use of the Moodle platform facilitates the educational process & $3.19(0.82)$ & $3.03(0.56)$ & 0.95 \\
\hline 26. Weblogs facilitate peer to peer and student-teacher communication & $3.17(0.77)$ & $3.00(0.54)$ & 1.05 \\
\hline 27. The use of wikis allows to learn and share contents & $3.42(0.77)$ & $3.03(0.74)$ & $2.10^{*}$ \\
\hline 28. Weblogs facilitate social interaction and the exchange of opinions & $3.36(0.72)$ & $3.18(0.57)$ & 1.18 \\
\hline $\begin{array}{l}\text { 29. The use of blogs facilitates information on news, topics of interest } \\
\text { and events related to the university subject }\end{array}$ & $3.39(0.73)$ & $3.29(0.46)$ & 0.72 \\
\hline 30. Forums facilitate the dynamic exchange of information & $3.29(0.82)$ & $3.06(0.55)$ & 1.35 \\
\hline $\begin{array}{l}\text { 31. Online tutors allow students to solve doubts and facilitate the teach- } \\
\text { ing/learning process }\end{array}$ & $3.06(0.75)$ & $2.91(0.92)$ & 0.71 \\
\hline 32. Online questionnaires help clarifying and assimilating contents & $2.95(0.79)$ & $2.83(0.75)$ & 0.63 \\
\hline 33. Power point presentations facilitate the learning process & $3.19(0.71)$ & $2.86(0.76)$ & 1.77 \\
\hline
\end{tabular}

Statistical Significance. ${ }^{*} p<0.05 ; * * p 0.01$ 


\section{PROBLEMS \\ OF EDUCATION \\ IN THE $21^{\text {st }}$ CENTURY \\ Volume 43, 2012 \\ 54 \\ Discussion}

The first section of the present study dealt with an accurate evaluation of interests and attitudes towards ICT on the part of post-graduate students of the Master's Degree in Teacher Training: Secondary and Upper Secondary Education, Vocational Training and Language Teaching at the University of Malaga. Results showed that (1) all students are familiar with the Internet and that (2) they first got to know it from friends. More important is the fact that most of them consider the Internet as a potential educational resource and not only as a support or reinforcement tool that complements the textbook. Most students and teachers like to use ICT and think of them as useful tools in their learning/teaching process.

In general terms, post-graduate students show a very positive attitude towards ICT, using them as a communication tool (with a clear predominance of the use of email) as well as for activities related to information research, transmission and presentation. These results are consistent with earlier studies that show an increased use of ICT, given that students consider them to have a motivational impact and see them as relevant educational resources (Martínez and Aguaded, 2004). Additionally, most students think that ICT promotes the use of other languages. As a matter of fact, ICT are being increasingly used in language centres to encourage reading and to teach languages. To conclude, it is worth stressing that most students think that the Internet cannot replace the teacher, but that ICT can be used to educate about diversity. These two aspects form the backdrop for a comprehensive education, which aims to improve interpersonal relationships and social integration. In fact, some experts (Javaloy, Espelt and Cornejo, 2001) think that ICT contribute to promoting social aspects as important as social awareness and social values, hence the need to use them with this purpose in mind.

It is worth highlighting that post-graduate students who took part in this study gave a lot of importance to the use of Web 2.0 cooperative tools (forums, wikis, chats, blogs, social networks) for their training on competences. Such results are consistent with further studies (Fernández and Mena, 2010; Ríos and Ruiz, 2011) showing that the use of these tools has great potential in the educational field; both in formal and informal learning, as students can use them to express themselves whilst promoting interpersonal relationships and communication with other members within and outside the educational community.

As stated in former studies, and according to data provided by the Spanish Institute of Communication Technologies (2009), 69\% of social network users in Spain are aged between 15 and 34. The potential of this tool must therefore also be taken into account for educational purposes. In fact, according to Castañeda (2010), it is necessary to discuss social networks in relation to education from three complementary educational approaches: 1) learning with social networks (which takes place within formal and non-formal education); 2) learning by means of social networks (informal learning where network users can autonomously and independently learn how to take part in the network); and 3) learning to live in a world of social networks (the need to inform and raise awareness of the fact that their use will broaden their possibilities, as well as of the different roles they can play in our lives). Social networks play a significant role in our lives and education cannot remain indifferent to this reality.

Coming back to the purpose of the present study - to analyse differences based on gender and specialization in students' predisposition and perception of ICT applications-, results show that there are gender-based differences in students' perception of ICT applications in the university context, as well as in students' predisposition to use them. In particular, men from the specialization Foreign Language consider that weblogs do facilitate peer-to-peer and student-teacher communication and give less importance than women to the item stating that the families' socioeconomic level has an influence on our knowledge of the Internet. These results are consistent with further research (Wallace and Clariana, 2005) where the gender variable is considered relevant to this type of study. 
However, significant gender-based differences only appear in those aspects related to students' predisposition and perception of ICT applications. This result is consistent with other studies that do not find statistically significant differences between men and women (Adebanjo, 2004; Hoxmier, Nie and Purvis, 2000; Tekinarslan, 2008) in relation to aspects related to knowledge and the use of computers. Likewise, statistically significant differences have also been found in relation to students' perception and attitudes towards ICT according to specialization. The most significant results show that post-graduate students from the specialization Foreign Language show a higher predisposition to use ICT in the university context as compared to students from the specialty Literature, Latin and Greek. However, further data is currently being analysed - such as teachers of the same Master's Degree' predisposition to use ICT. It is important to keep investigating such variables in detail in order to achieve conclusive results in this area.

The educational world cannot remain indifferent to the on-going transformation of universities as well as of society in general. Digital technologies provide for many possibilities in the educational context: they promote the development of knowledge, procedures and mainstreaming of skills such as social competences, communication and organisational skills, and the possibility of digital training for teachers and students. The competences associated to ICT allow students and teachers to be in touch with different realities and adds to their personal enrichment. Furthermore, these competences eliminate or reduce barriers in terms of access to the resources and opportunities offered by higher education. Additionally, they facilitate cooperative approaches to learning; favour autonomous learning; and promote new approaches to teaching and learning, which, to say the least, can complement a traditional approach. Among many other advantages, these competences provide effective feedback and on-going information exchange, which are both necessary aspects in the educational context.

\section{Conclusions}

The present study provides an accurate evaluation of interests and attitudes towards ICT by post-graduate students of the Master's Degree in Teacher Training. Such evaluation is rendered necessary within the current European convergence process. Results show that postgraduate students who took part in this study have a very positive predisposition towards using ICT in their learning process. Additionally, they give a lot of importance to Web 2.0 cooperative tools (forums, wikis, chats, blogs, social networks) to train their competences.

Furthermore, results show that there are gender-based differences and specializationbased differences in students' perception of ICT applications in the university context. In relation to the former (gender), results show that men believe that weblogs facilitate peer-to-peer and student-teacher communication more than women. In relation to the latter (specialization), results show that post-graduate students from the specialization Foreign Language show a higher predisposition to use ICTs in the university context as compared to students from the specialty Literature, Latin and Greek.

To conclude, the information obtained from the present study is of interest both for training teachers and for integrating ICT in the academic curricula. The relevant data obtained can contribute to the optimization of the teaching/learning process in the Master's Degree in Teacher Training: Secondary and Upper Secondary Education, Vocational Training and Language Teaching, which has been very recently incorporated into the academic program of the University of Malaga. 
PROBLEMS

OF EDUCATION

IN THE $21^{\text {st }}$ CENTURY

Volume 43, 2012

\section{Acknowledgements}

We would like to thank students from the Master's Degree in Teacher Training: Secondary and Upper Secondary Education, Vocational Training and Language Teaching, of the University of Malaga, for their good will in answering all the questions included in the study.

\section{References}

Adebanjo, A. A. (2004). The Attitude and Gender Difference in the Utilization of Computer among Undergraduates. Journal of Computer Literacy, 5, 171-183.

Barroso, J., \& Cabero, J. (2010). La investigación educativa en TIC. Visiones prácticas. [Education Research in ICT: Practical Insights]. Madrid: Síntesis.

Bartolomé, A. (2008). Vídeo digital y educación. [Digital Video and Education]. Madrid: Síntesis.

Cabero, J., \& Gisbert, M. (2005). Formación en Internet. Guía para el diseño de materiales didácticos. [Online Training: Guide for Designing Teaching Materials].Sevilla: MAD.

Carr, N. (2011). Aguas superficiales. ¿Qué está haciendo Internet con nuestras mentes? [Surface Waters: What is the Internet Doing with Our Minds?]. Madrid: Taurus.

Castañeda, L. (2010). Aprendizaje con redes sociales. Tejidos educativos para los nuevos entornos. [Learning with Social Networks: Educational Fabric for New Environments]. Sevilla: MAD.

Cebrián, M., \& Gallego, M. J. (2011). Procesos educativos con TIC en la sociedad del conocimiento. [Educational Processes with ICT in the Knowledge Society]. Madrid: Pirámide.

De Pablos, J. (2009). Tecnología educativa. La formación del profesorado en la era de Internet. [Educational Technology: Teacher Training in the Internet Era]. Málaga: Aljibe.

De Pablos, J., Area, M., Valverde, J., \& Correa, J. M. (2010). Políticas educativas y buenas prácticas con TIC. [Education Policies and Good Practice with ICT]. Barcelona: GRAÓ.

Fernández, M. A., \& Mena, E. (2010). El tutor 2.0: Aplicaciones para entornos virtuales de aprendizaje. [The 2.0 Tutor: Applications for Virtual Learning Environments]. Málaga: Aljibe.

García-Valcárcel, A. (2007). Herramientas tecnológicas para mejorar la docencia universitaria. Una reflexión desde la experiencia y la investigación. [Technological Tools to Improve University Teaching: A Reflection Based on Experience and Research]. Revista Iberoamericana de Educación a Distancia, 10, 125-148.

Hoxmier, J. A., Nie, W., \& Purvis, G. T. (2000). The Impact of Gender and Experience on User Confidence in Electronic Mail: Industry Trend or Event. Journal of End User Computing, 7, 99-106.

Spanish Institute of Communication Technologies (2009). Estudio sobre la privacidad de los datos personales y la seguridad de la información en las redes sociales online. [Study on the Privacy of Personal Data and Information Security in Online Social Networks]. (online document). Retrieved 10/08/2011, from www.inteco.es.

Javaloy, F., Espelt, E., \& Cornejo, J. M. (2001). Internet y movimientos sociales: un enfoque psicosocial. [Internet and Social Movements: A Psychosocial Approach]. Anuario de Psicología, 32, 31-37.

Martínez, T., \& Aguaded, J. (2004). El uso de las TIC en alumnos principiantes de las universidades españolas. [The Use of ICT by Beginner Students in Spanish Universities]. Granada: GEU.

Morales, F. M. (2009, December). Empleo de TIC en la enseñanza práctica: Análisis comparativo en diferentes titulaciones universitarias. [The Use of ICT in Practical Teaching: Comparative Analysis in Different University Degrees]. Paper presented at the First International Conference on Use and Good Practice of ICT, University of Malaga, Spain.

Pereira, C. (2003). El cine, nuevo escenario de la educación. [The Cinema: A New Platform for Communication]. In Romañá Blay, M. T. \& Martínez Martín, M. (Eds.), Otros lenguajes en educación. Barcelona: ICE-Universitat de Barcelona, pp. 101-105. 
Francisco Manuel MORALES RODRÍGUEZ. Evaluation of Attitudes and Interests towards ICT: Orientation for Problem Experiences

Ríos, J. M., \& Ruiz, J. (2011). Competencias, TIC e innovación. Nuevos escenarios para nuevos retos. [Competences, ICT and Innovation: New Scenarios for New Challenges]. Sevilla: MAD. ., \& Álvarez, A. (2010). Formación de formadores después de Bolonia. [Teacher Training After Bologna]. Madrid: Díaz de Santos.

Sangrá A., \& González, M. (2004). La transformación de las universidades a través de las TIC: discursos y prácticas. [Transforming Universities Through ICT: Speeches and Practice]. Barcelona: UOC.

Tekinarslan, E. (2008). Computer Anxiety: A Cross-cultural Study of Dutch and Turkish University Students. Computers in Human Behaviour, 24, 1572-1584.

Trujillo, A. (2005). Nuevas tecnologías y psicología. Una perspectiva actual. [New Technologies and Psychology: A Current Approach]. Apuntes de Psicología, 23, 321-335.

Wallace, P., \& Clariana, R. B. (2005). Gender Difference in Computer-Administered Versus Paper-Based Tests. International Journal of Instructional Media, 32, 37-45.

Advised by Martin Bilek, University of Hradec Kralove, Czech Republic

Received: May 04, 2012

Accepted: June 12, 2012

Francisco Manuel Morales

Rodríguez
$\mathrm{PhD}$ in Psychology and Bachelor of Labour, Associate Professor (Doctor), Department of Psychology and Education, School of Psychology, University of Malaga, Campus de Teatinos s / n, 29071, Spain.

E-mail: framorrod@uma.es

Website: http://webdeptos.uma.es/psicoev/ 